\title{
PENGARUH KETERGANTUNGAN PADA SMARTPHONE DAN SIKAP TERHADAP PERILAKU PEMBELIAN ONLINE PADA MAHASISWA
}

\author{
Oleh \\ Tri Widodo \\ Dosen Tetap STIE AMA Salatiga \\ Rina Sari Qurniawati \\ Dosen Tetap STIE AMA Salatiga
}

\begin{abstract}
Abstrak
Kemajuan teknologi pada beberapa dekade terakhir telah mengubah cara kita dalam mengkonsumsi, mendistribusikan, dan menciptakan informasi secara signifikan. Apalagi dengan kedatangan internet, yang secara total merubah cara bisnis dilakukan diseluruh dunia. Indonesia menjadi negara dengan pertumbuhan pasar ecommerce terbesar di dunia dengan rata-rata pertumbuhan 17 persen setiap tahun. Dalam beberapa tahun terkakhir, ponsel telah berkembang yang pada awalnya hanya perangkat komunikasi interpersonal menjadi mesin multimedia yang lebih kita kenal dengan sebutan ponsel pintar (Smartphone). konsumen dianggap tergantung pada smartphone ketika mereka melihat itu sebagai kebutuhan dan memiliki kecenderungan yang kuat untuk menggunakannya secara terus menerus, merasa terlibat dan enggan untuk terpisah. Penelitian ini bertujuan untuk menguji pengaruh ketergantugan pada smartphone dan sikap pada perilaku pembelian online pada mahasiswa. Hipotesis yang dikembangkan diuji menggunakan data yang diperoleh melalui survey pada 60 mahasiswa di Salatiga dan Surakarta. Pengujian pada penelitian ini menggunakan regresi sederhana. Program statistik SPSS digunakan untuk menguji validitas dan reliabilitas instrument dan hipotesis penelitian.

Hasil dari penelitian ini adalah terdapat hubungan antara ketergantungan pada smartphone terhadap perilaku pembelian online mahasiswa. Sedangkan tidak ada pengaruh antara sikap terhadap perilaku pembelian online mahasiswa. Hal ini dikarenakan responden merasakan adanya kemudahan dalam berbelanja online akan tetapi masih merasakan adanya risiko yang mungkin muncul sehingga mereka belum begitu menjadikan belanja online sebagai pilihan utama.
\end{abstract}

Kata Kunci : smartphone, sikap, Perilaku pembelian online 


\section{PENDAHULUAN}

Saat ini, masyarakat melihat informasi sebagai salah satu kebutuhan pokok disamping kebutuhan akan sandang, pangan dan papan. Seiring dengan hal itu, informasi telah berubah bentuk menjadi suatu komoditi yang dapat diperdagangkan. Kemajuan teknologi pada beberapa dekade terakhir telah mengubah cara kita dalam mengkonsumsi, mendistribusikan, dan menciptakan informasi secara signifikan. Apalagi dengan kedatangan internet, yang secara total merubah cara bisnis dilakukan diseluruh dunia. Sekarang konsumen mempunyai banyak pilihan saluran untuk berbisnis. Salah satu alternatif yang tersedia bagi masyarakat adalah e-commerce. Aktifitas bisnis secara elektronik ini (e-commerce) telah memberikan beberapa kemudahan baik bagi penjual maupun pembeli (Grandon \& Pearson 2004). Bagi pihak penjual, e-commerce akan membantu untuk memperluas daerah pemasaran produk yang akan dijualnya, sedangkan bagi pembeli, akan mempermudah mendapatkan dan membandingkan informasi tentang produk yang akan dibelinya.

Menurut data yang dirilis biro riset Frost \& Sullivan, bersama China, Indonesia menjadi negara dengan pertumbuhan pasar e-commerce terbesar di dunia dengan rata-rata pertumbuhan 17 persen setiap tahun. Ramainya pengguna e-commerce di Indonesia membuat nilai transaksinya terus bertumbuh. Menurut Bank Indonesia, nilai transaksi $e$ commerce pada tahun 2014 mencapai US\$2,6 miliar atau setara dengan Rp34,9 Triliun.

Hasil survei MasterCard tahun 2013 di 14 pasar Asia dan Pasifik mendapatkan temuan bahwa aplikasi mobile banking memiliki tingkat awareness tertinggi yaitu sebesar $45 \%$, diikuti oleh 2 aplikasi belanja melalui jejaring sosial sebesar 34\%, aplikasi belanja

untuk permainan (game) sebesar 33\% dan SMS/MMS berbasis pembayaran sebesar 31\% (Joice, 2013). Di Indonesia, setengah dari pembeli online menggunakan Facebook (50\%) dan jejaring sosial Kaskus $(49,2 \%)$ untuk membeli barang, mulai produk fashion, elektronik, buku, hingga peralatan rumah tangga (Setyawati, 2012).

Dalam beberapa tahun terkakhir, ponsel telah berkembang yang pada awalnya hanya perangkat komunikasi interpersonal menjadi mesin multimedia yang lebih kita 
kenal dengan sebutan ponsel pintar (Smartphone). Penyebutan ponsel pintar merujuk pada ponsel yang diprogram untuk menawarkan kemampuan canggih dan fitur yang membantu individu dalam pekerjaan dan kehidupan mereka sehari-hari (Euromonitor, 2010).

Di Indonesia sendiri perkembangan pengguna telepon pintar berkembang dengan pesat. Pada akhir 2015 diperkirakan terdapat sekitar 55 juta pengguna ponsel pintar, sedangkan total penetrasi pertumbuhannya mencapai 37,1 persen. Kalangan muda khususnya mahasiswa, sering kali dikategorikan sebagai kelompok konsumen yang cenderung terbuka terhadap produk baru yang dimunculkan di pasar. Kelompok ini juga diyakini selalu ingin mengikuti tren gaya hidup terkini, terlepas dari apakah sesungguhnya mereka benar-benar membutuhkan produk tersebut dan mendapat manfaat dari produk yang dikonsumsinya (Schiffman dan Kanuk, 2007:316). Smith dan Caruso (2010) melaporkan bahwa 63\% sarjana di Amerika Utara sekarang mempunyai ponsel pintar. Lebih dari setengah dari mereka menyatakan bahwa mereka mengakses internet melalui perangkat mereka hampir tiap hari untuk membaca dan mengirim e-mail, mengakses media sosial, membaca berita, dan mendapatkan peta dan petunjuk arah. Grup pelajar di Amerika juga menggunakan ponsel mereka untuk melakukan transaksi perbankan online, belanja, dan download atau streaming musik.

Sementara itu, pemasar telah mengidentifikasi banyak faktor yang mempengaruhi keputusan pembelian oleh konsumen dan perilaku pembelian secara online. Jarvenpa dan Todd (1996-1997) dalam Yin-Fah dan Hooi-Choo (2010) mengklasifikasikan faktorfaktor ini ke dalam empat kelompok persepsi pembelian yang mempengaruhi keputusan pembelian konsumen. Kelompok persepsi pembelian ini adalah: pemahaman terhadap produk, pengalaman belanja, layanan pelanggan dan risiko konsumen. Pemahaman terhadap produk atau yang sering disebut persepsi produk, menjadi determinan utama dimana konsumen memilih untuk berbelanja. Harga, kualitas produk dan jenis produk adalah persepsi produk yang paling berpengaruh dikutip di dalam literatur. Pengalaman belanja adalah kluster kedua determinan yang terdiri dari ketersediaan produk, usaha, kesesuaian gaya hidup, dan kenikmatan dari proses belanja. Layanan pelanggan adalah 
kluster ketiga yang mempengaruhi keputusan pembelian, termasuk penjual, responsif, dan kehandalan. Kluster keempat yaitu persepsi pembelian tediri dari ekonomi, sosial, kinerja personal dan dimensi risiko privasi yang biasayaa masuk dalam risiko konsumen.

Tien et al. (2009), konsumen dianggap tergantung pada smartphone ketika mereka melihat itu sebagai kebutuhan dan memiliki kecenderungan yang kuat untuk menggunakannya secara terus menerus, merasa terlibat dan enggan untuk terpisah. Setelah digunakan atau telah sangat terlibat dengan smartphone berarti konsumen tidak hanya memiliki pengetahuan pribadi tentang atribut mereka tetapi juga mengalami pengetahuan pribadi tentang bagimana cara kerja bagi para konsumen dan bagaimana mereka memenuhi kebutuhan (Keaveney dan Parathasarathy, 2001).

Berdasarkan uraian di atas, penulis tertarik untuk melakukan penelitian yang bertujuan untuk menguji pengaruh ketergantungan terhadap smartphone dan sikap terhadap perilaku pembelian online pada mahasiswa.

\section{RUMUSAN MASALAH}

Berdasarkan latar belakang di atas, maka rumusan masalah pada penelitian ini adalah

1. Apakah ketergantungan terhadap smartphone berpengaruh positif pada perilaku pembelian online pada mahasiwa?

2. Apakah sikap berpengaruh positif pada perilaku pembelian online pada mahasiwa?

\section{TUJUAN PENELITIAN}

Sesuai dengan permasalahan penelitian, maka tujuan penelitian ini adalah:

1. Menemukan bukti empiris adanya pengaruh ketergantungan terhadap smartphone pada perilaku pembelian online pada mahasiwa.

2. Menemukan bukti empiris adanya pengaruh sikap pada perilaku pembelian online pada mahasiwa. 


\section{MANFAAT PENELITIAN}

Penelitian diharapkan akan memberi manfaat baik peneliti, praktisi, maupun akademisi. Adapun manfaat penelitian ini adalah:

\section{Bagi Peneliti}

Penelitian ini bermanfaat untuk dapat lebih menperdalam ilmu pemasaran dan perilaku konsumen, khususnya faktor-faktor yang menjadi pendorong konsumen melakukan pembelian produk secara online.

\section{Bagi Praktisi}

Penelitian ini diharapkan dapat memberikan sumbangan informasi dan pemikiran bagi praktisi (pemasar) untuk menjadi bahan pertimbangan bagaimana seharusnya mempelajari perilaku pembelian yang dilakakukan dengan menggunakan media internet (online). Dengan demikian pemasar dapat menerapkan startegi-strategi khusus yang dapat meningkatkan penjualan mereka.

\section{Bagi Akademisi}

Hasil penelitian yang didapatkan nanti diharapkan dapat berguna sebagai bahan pertimbangan bagi penelitian selanjutnya, terutama untuk penelitian yang berkaitan dengan faktor-faktor yang mendorong konsumen lebih memilih untuk berbelanja secara online, khususnya pembelian yang dilakukan oleh para mahasiswa.

\section{PAPARAN TEORITIS}

\section{Ketergantungan Terhadap Smartphone}

Lonjakan penggunaan smartphone di Indonesia dan penggunaannya yang besar di kalangan mahasiwa mendorong pentingnya memahami penentu yang menciptakan ketergantungan pada smartphone di pasar segmen mahasiswa dan membentuk kemauan orang-orang muda untuk membeli smartphone. Menurut Tien et al. (2009), konsumen dianggap tergantung pada smartphone ketika mereka melihat itu sebagai kebutuhan dan memiliki kecenderungan yang kuat untuk menggunakannya secara terus menerus, merasa terlibat dan enggan untuk terpisah. Setelah digunakan atau telah sangat terlibat dengan 
smartphone berarti konsumen tidak hanya memiliki pengetahuan pribadi tentang atribut mereka tetapi juga mengalami pengetahuan pribadi tentang bagimana cara kerja bagi para konsumen dan bagaimana mereka memenuhi kebutuhan (Keaveney dan Parathasarathy, 2001).

Ting et al. (2011) dan Mohd Suki (2013) menyoroti fakta tentang pembelian perilaku pembelian terutama terkait dengan ketergantungan mereka pada smartphone. Dimana ketergantungan pada smartphone tercipta berkat tekanan sosial, keinginan konsumen, dan kecekatan smartphone bagi mahasiswa. Sebagai tambahan, setiap pengalaman negatif dari penggunaan smartphone ditutupi dengan pengalaman positif yang mereka dapatkan, yang pada gilirannya menyebabkan penggunaan yang lebih besar.

Pemberdayaan yang dirasakan oleh pengguna smartphone sebagai sebuah kebebasan dan itu dilihat oleh mereka sekarang menjadi sebuah keharusan untuk menggunakan smartphone secara terus menerus. Menggunakan smartphone membuat konsumen ikut serta dengan cara memperbolehkan mereka untuk meningkatkan pengetahuan pribadi tentang karakteristik mereka dan bagaimana mereka bekerja untuk memenuhi kebutuhan dan meningkatkan pengalaman pribadi (Kuhlmeier dan Knight, 2005). Baru-baru ini Mohd Suki (2013) dan Duffet (2015) merekomendasikan bahwa investigasi ketergantungan mahasiswa terhadap smartphone harus dilakukan di negara berkembang . hali ini dilalakukan untuk mendapatkan temuan yang lebih holistik dan akurat tentang perilaku pembelian smartphone dan bagaimana mereka mencerminkan persepsi studi tersebut.

Hal ini didukung oleh Mafe dan Blas (2006) yang menemukan bahwa ketergantungan konsumen yang tinggi pada smartphone berkorelasi positif dengan perilaku pembelian masa depan konsumen. Selain itu, konsumen yang memiliki pengalaman sebelumya dengan smartphone dapat belajar dengan cepat dari pengalaman mereka (Kim, 2008). Apakah dari pengalaman ketergantungan terhadap smartphone itu bersifat positif maupun negatif, konsumen akan cepat menyesuaikan evaluasi mereka berikutnya ketika akan melakukan pembelian smartphone berikutnya (Keaveney dan Parthasarathy, 2001). 


\section{Sikap}

Ajzen (1988) mendefinisikan sikap sebagai predisposisi yang dipelajari individu untuk memberikan respon suka atau tidak suka secara konsisten terhadap objek sikap.. Sikap terhadap perilaku ditentukan oleh kepercayaan tentang konsekuensi dari sebuah perilaku, yang disebut sebagai behavioral beliefs (Ajzen, 2005). Menurut Ajzen (2005) setiap behavioral beliefs menghubungkan perilaku dengan hasil yang bisa didapat dari perilaku tersebut. Sikap terhadap perilaku ditentukan oleh evaluasi individu mengenai hasil yang berhubungan dengan perilaku dan dengan kekuatan hubungan dari kedua hal tersebut (Ajzen, 2005). Menurut Ajzen (2005) sikap terhadap perilaku didefinisikan sebagai derajat penilaian positif atau negatif individu terhadap perilaku tertentu.

Konsisten dengan literatur dan model perubahan sikap dan perilaku (Fishbein dan Ajzen, 1975), diyakini bahwa sikap konsumen akan mempengaruhi niat untuk berbelanja online dan akhirnya memutuskan untuk melakukan adanya suatu transaksi. Pertama, mengacu pada penerimaan konsumen terhadap internet sebagai saluran belanja (Jahng et al., 2001). Kedua, mengacu pada sikap konsumen terhadap toko internet tertentu (misalnya, sejauh mana konsumen berpikir bahwa berbelanja di toko tersebut adalah menarik). Sikap dapat dibentuk berdasarkan informasi tentang perilaku masa lalu, informasi afektif, dan informasi kognitif (Zanna dan Rempel, 1988). Berbeda dengan fase pra-adopsi, dimana pengguna bergantung pada sumber-sumber sekonder ketika membentuk sikap, dalam konteks pasca-adopsi, pengguna memiliki pengalaman dengan sistem. Pengalaman tangan petama ditemukan untuk memperkuat hubungan antara sikap dan niat perilaku (Karahanna et al., 1999).

Menurut model CAB oleh Martinez-Lopez et al. (2005), sikap disusun oleh kepercayaan atayu cognitions (C), penggaruh atau affect (A), dan perilaku atau behavior (B). Model $\mathrm{CAB}$ telah ditemukan memiliki validitas dalam menjelaskan penggunaan belanja online ktika konsumen sangat terlibat dalam pengalaman berinternet terutama salam memproses pesan persuasive. Menurut model CAB, diasumsikan bahwa basis kepercayaan konsumen terakumulasi pada pengetahuan mereka terhadap beberapa atribut kunci dari objek yang kemudian diikuti oeh perilaku (B). Sorce et al. (2005) menyatakan 
bahwa faktor sikap menjelaskan lebih bervariasi dalam memprediksi perilaku pembelian online daripada usia.

\section{Perilaku Pembelian Online}

Pemahaman mengenai perilaku konsumen sangatlah penting dalam pemasaran. Menurut Engel, et al. (1994), perilaku konsumen adalah suatu tindakan yang langsung terlibat dalam mendapatkan, mengkonsumsi, dan menghabiskan produk dan jasa, termasuk keputusan mendahului dan menyusuli tindakan ini. Terdapat dua elemen penting dari arti perilaku konsumen, yaitu: (1) proses pengambilan keputusan, (2) kegiatan fisik yang melibatkan individu dalam menilai, mendapatkan dan menggunakan barang dan jasa ekonomis (Swastha, 1990).

Menurut Kotler dan Amstrong (2001), terdapat beberapa faktor yang mempengaruhi perilaku konsumen, diantaranya yaitu faktor psikologis. Adapun macam dari faktor psikologis ini antara lain, yaitu: (1) Motivasi-adalah suatu kebutuhan yang secara cukup dirangsang untuk membuat seseorang mencari kepuasan atas kebutuhannya; (2) Persepsi-adalah proses dimana seseorang memilih, mengatur, dan menginterpretasikan informasi untuk membentuk gambaran yang berarti mengenai dunia; (3) Pembelajaran - adalah perubahan pada perilaku individu yang muncul dari pengalaman; (4) Keyakinan-adalah pemikiran deskriptif seseorang mengenai sesuatu, dan sikap-menggambarkan penilaian, perasaan, dan kecenderungan yang relatif konsisten dari seseorang atas sebuah obyek atau gagasan.

Kedatangan internet secara total mentransformasi bagaimana bisnis di jalankan. Telah terjadi pergeseran kearah belanja online karena kemudahan, kenyamanan, penghematan biaya, penghematan waktu dan pengiriman yang cepat dibandingkan dengan belanja konvensional atau tradisional. Konsumen tidak terikat lagi dengan waktu atau lokasi untuk melakukan transaksi mereka. Untuk membeli produk hanya membutuhkan beberapa klik saja sebagai akibat dari pertumbuhan yang cepat dan $e$ commerce. Peningkatan belanja online telah memaksa perusahaan untuk menawarkan produk dan layanan online. Ini membantu mereka mendapatkan keuntungan kompetitif atas perusahaan lain di pasar. 
Tren global menunjukkan pergeseran kearah e-commerce. Dengan demikian, popularitas dari e-commerce benar-benar menjadi fenomena global. Menurut Guardian, Inggris memiliki pasar terbesar e-commerce pada tahun 2010. E-commerce China juga berkembang dengan pesat, statistik menunjukkan bahwa penjualan online di China pada tahun 2009 menyentuh hampir $\$ 36,6$ juta (Forbes, 2010). Negara lain seperti Korea Selatan, Jepang, Brazil, Prancis, Jerman dan Rusia juga telah melihat adanya perkembangan di sektor e-commerce di negara mereka.

Di Indonesia sendiri pertumbuhan pesat pasar e-commerce sudah tidak bisa diragukan lagi. Dengan jumlah pengguna internet yang mencapati 82 juta orang, pasar $e$ commerce menjadi peluang bisnis bagi sebagian orang yang melihat potensi ke depannya. Nilai transaksi e-commerce pada tahun 2013 di Indonesia sudah mencapai angka tahun Rp 130 triliun (Menkominfo, 2013). Ini merupakan angka yang sangat fantastis mengingat bahwa hanya sekitar $7 \%$ pengguna internet di Indonesia yang pernah berbelanja secara online.

\section{Hasil-hasil Penelitian Terdahulu dan Perumusan Hipotesis}

Berkembangnya Smartphone dengan peningkatan spesifikasi dan fungsi ponsel yang semakin meingkat akan menggeser peran dari ponsel biasa yang hanya bisa digunakan untuk telepon dan mengirim pesan. Smartphone menawarkan beragam konten internet dengan berbagai pilihan multimedia, misalnya pengguna dapat mem-download berbagai jenis aplikasi yang mempermudah akrivitas mereka (Arif et al., 2016). Kebutuhan akan smartphone yang tinggi akan mempengaruhi ekspektasi konsumen terhadap pembelian masa depan mereka. Mereka sangat bergantung pada smartphone karena manfaat yang didapatkan sangat besar (Khulmeier dan Knight, 2006.

Penelitian dari Ting et al. (2011) menunjukkan adanya pengaruh yang positif antara ketergantungan mahasiswa terhadap smartphone dan perilaku pembelian mereka di masa datang. Indikasi dari penelitian ini adalah bahwa mahasiswa yang memiliki ketergantungan yang tinggi terhadap smartphone cenderung membuat evaluasi berdasarkan pengalaman masa lalu mereka untuk menentukan perilaku pembelian mereka di masa depan. Pengalaman positif mahasiwa dengan smartphone telah melebihi 
pengalaman negatif yang mereka dapatkan, sehingga penggunaan smartphone juga tetap tinggi.

\section{H1: Pengaruh ketergantungan terhadap smartphone terhadap perilaku pembelian online}

Sikap dapat dibentuk berdasarkan informasi tentang perilaku masa lalu, informasi efektif dan informasi kognitir (Zanna dan Rempel, 1988) dalam Mantymaki dan Salo (2011). Sikap merupakan faktor penting dari kecenderungan individu untuk merespon dan memiliki hubungan yang positif dengan perilaku. Javadi et al. (2012) menyatakan bahwa sikap konsumen terhadap belanja online secara signifikan mempengaruhi perilaku belanja mereka. Jadi ketika konsumen memiliki sikap yang signifikan terhadap belanja online, ini akan memiliki efek pada perilaku belanjanya. Studi yang ada menunjukkan bahwa sikap merupakan prediktor penting perilaku menggunakan internet untuk melakukan pembelian (Andrews dan Bianchi, 2013).

\section{H2: Pengaruh sikap terhadap perilaku pembelian online}

Berdasarkan rangkuman dari hasil-hasil studi terdahulu dan hipotesis yang telah dirumuskan, maka dibentuklah rerangka pemikiran untuk penelitian ini (lihat Gambar 1.).

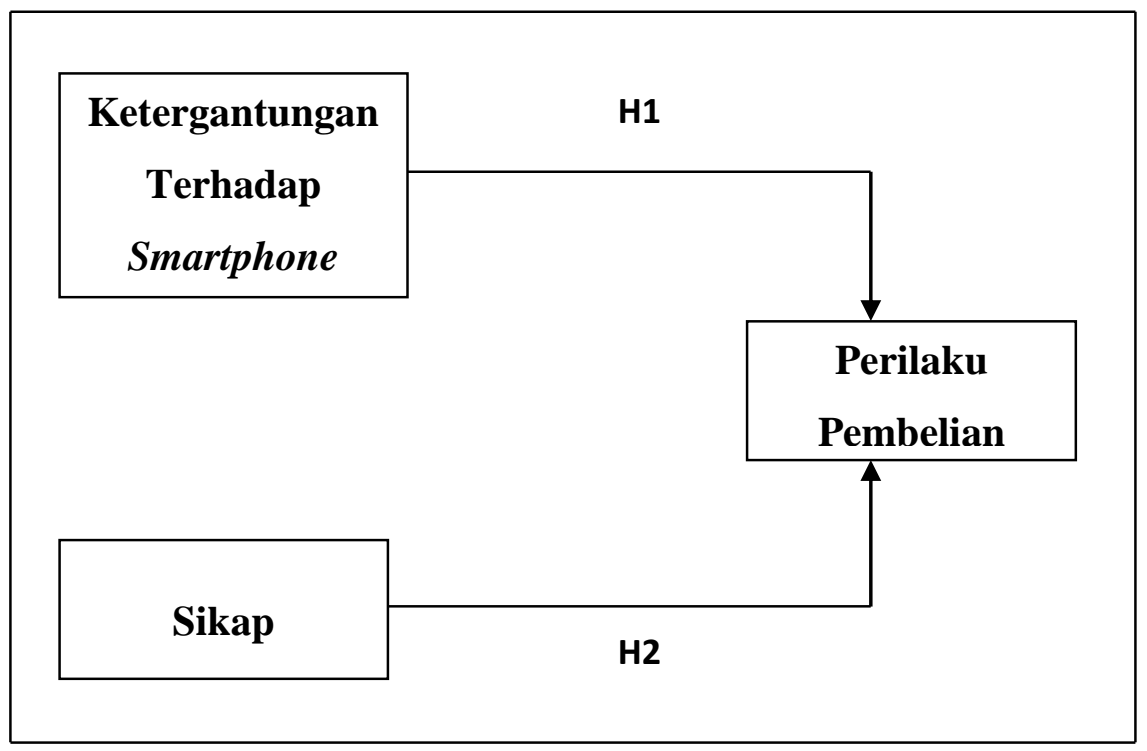

Gambar 1

Skema Rerangka Pemikiran 


\section{METODE PENELITIAN}

\section{Teknik dan Prosedur Pengumpulan Data}

Penelitian ini dilakukan dengan menggunakan metode survey dengan tipe selfadministered questionnaires. Menurut Cooper dan Schindler (2008), survei adalah proses pengukuran yang digunakan untuk mengumpulkan data dengan penggunaan tingkat interview yang tinggi, dengan memakai interviewer atau tidak memakai interviewer dalam proses pengumpulan data. Peneliti mengumpulkan data primer secara langsung dengan membagikan kuesioner untuk diisi oleh responden yang memiliki kriteria sebagaimana yang telah ditentukan sebelumnya

\section{Metode Pengambilan Sampel (Sampling)}

Metode pemilihan sampel (sampling) dalam penelitian ini dilakukan secara non probability dengan teknik purposive sampling. Selain karena keterbatasan waktu, tenaga, dan biaya, alasan utama pengambilan sampel dilakukan secara non probability ialah karena dalam penelitian ini peneliti tidak memiliki list anggota populasi dari mahasiwa yanga kan dijadikan sampel. Teknik purposive sampling atau sampel bersyarat digunakan berdasarkan pada kriteria sebagai berikut: Peneliti perpendapat bahwa mahasiswa seringnya adalah pengadopsi awal teknologi baru, khususnya yang berkaitan dengan ponsel pintar (Kim dan Parka, 2014). Dalam meneliti hubungan antara usia dan motivasi belanja internet, Dholakia dan Uusitalo (2002) menemukan bahwa konsumen yang lebih muda adalah konsumen yang lebih hedonis dalam berbelanja online daripada konsumen yang lebih tua. Berdasarkan laporan dari Pew Internet, 52 persen dari usia 18 - 29 tahun memiliki ponsel pintar di tahun 2011, sedangkan usia 50-64 tahun hanya sebesar 24 tahun (Smith, 2011). Selain itu, laporan dari eMarketer memperlihatkan bahwa 61 persen mahasiswa merupakan pengguna ponsel pintar di tahun 2011. Selanjutnya, sebuah laporan mencatat bahwa tingkat pendidikan pemilik smartphone secara signifikan positif terkait dengan kepemilikan smartphone (Arief et al., 2016).

Adapun ukuran sampel yang akan digunakan, ditentukan berdasarkan pada metode Gay yaitu minimal unit sampel yang diambil adalah sebanyak 30 unit/ elemen (Sekaran, 
2003). Namun, untuk menghindari resiko adanya unit sampel yang cacat dan tidak dapat diolah, maka ukuran sampel yang direncanakan adalah sebanyak 60 responden.

\section{Variabel Penelitian}

Variabel independen dalam penelitian ini adalah ketergantugan terhadap smartphone dan Sikap. Sedangkan variabel dependen yang digunakan dalam penelitian ini adalah Perilaku Pembelian Online.

\section{Definisi Operasional Variabel}

Definisi operasional masing-masing variabel penelitian adalah sebagai berikut:

a) Perilaku pembelian online atau yang disebut juga pembelian secara online atau belanja internet mengacu pada proses pembelian produk atau jasa melalui internet. Proses ini terdiri dari lima langkah yang sama dengan perilaku belanja tradisional (Liang dan Lai, 2000). Dalam proses belanja online yang khas, ketika konsumen potensial menginginkan suatu barang atau jasa meraka akan akan membuka internet dan mencari informasi yang terkait dengan barang tersebut. Mereka akan mencari informasi yang mereka butuhkan kemudian akan mengevaluasi berbagai alternatif yang ada dan memilih kriteria yang paling mereka butuhkan. Akhirnya, transaksi terjadi dan pelayanan paska pembelian akan dilakukan. Konstruk perilaku pembelian online diukur menggunakan 5 item pertanyaan. Pengukuran variabel penelitian ini dilakukan dengan menggunakan skala Likert 5 point dari sangat tidak setuju sampai dengan sangat setuju. Pengukuran variabel sikap terhadap pembelian online didasarkan item-item pertanyaan yang dikembangkan oleh Arif et al.(2016).

b) Ketergantungan terhadap smartphone didefinisikan sebagai sebuah hubungan dimana kapasitas invididu mencapat tujuan mereka adalah bergantung terhadap sumber informasi yang dalam hal ini adalah penggunaan smartphone (Park et al., 2013). Smartphone memungkinkan para penggunanya untuk mencapai banyak tujuan penting dalam kehidupan sehari-hari mereka. Konstruk Ketergantungan terhadap smartphone diukur menggunakan 4 item pertanyaan. Pengukuran variabel penelitian ini dilakukan dengan menggunakan skala Likert 5 point dari sangat tidak setuju 
sampai dengan sangat setuju. Pengukuran variabel sikap terhadap pembelian online didasarkan item-item pertanyaan yang dikembangkan oleh Ting et al.(2011).

c) Sikap mengacu pada sebuah hipotesis konstruk yang merepresetasikan kesukaan dan tidak kesukaan terhadap sesuatu (Yin-Fah dan Hooi-Choo, 2010). Blackwell et al. (2006) menyatakan bahwa sikap adalah evaluasi melakukan perilaku tertentu yang melibatkan sikap objek, seperti membeli produk. Sikap secara umum merupakan pandangan positif atau negatif seseorang mengenai pembelian online. Konstruk sikap terhadap pembelian online diukur menggunakan 4 item pertanyaan. Pengukuran variabel penelitian ini dilakukan dengan menggunakan skala Likert 5 point dari sangat tidak setuju sampai dengan sangat setuju. Pengukuran variabel sikap terhadap pembelian online didasarkan item-item pertanyaan yang dikembangkan oleh Arif et al.(2016).

\section{Uji Validitas Dan Reliabilitas}

Validitas adalah derajat dimana suatu ukuran secara akurat menggambarkan apa yang seharusnya (Hair et al., 1998). Validitas insturmen penelitian ini diuji berdasarkan construct validity. Untuk menguji validitas konstruk, yang menunjukkan seberapa baik hasil yang diperoleh dari pengukuran alat ukur sesuai dengan teori dimana pengukuran itu disusun menggunakan convergent validity (Cooper dan Schindler, 2003). Convergent validity menunjukkan nilai-nilai yang diperoleh dari butir-butir instrumen yang mengukur konsep yang sama akan memiliki korelasi yang tinggi (Sekaran, 2003). Metode yang digunakan adalah Confirmatory Factor Analysis (CFA) dengan menggunakan bantuan software SPSS 11.5 for Windows yang mengindikasikan bahwa item-item yang digunakan untuk mengukur konstruk terlihat betul-betul mengukur konstruk tersebut. Batas ukuran valid digunakan adalah sebesar $\geq 0,40$ baik positir maupun negatif masih ditoleransi untuk diterima sebagai instrumen penelitian.

Uji reliabilitas dilakukan untuk mengetahui sejauh mana konsistensi suatu alat ukur. Reliabilitas merupakan syarat tercapainya validitas kuesioner dengan tujuan tertentu. Reliabilitas instrumen kuesioner diuji dengan menggunakan construct validity dengan menganalisis nilai Cronbach's Alpha $(\alpha)$ sebagai nilai koefisien reliabilitas. Hair et al., 
(2010) menyatakan bahwa sebuah item pertanyaan dapat dipertahankan jika memiliki nilai $\alpha \geq 0.6$.

\section{Metode Analisis Data}

Analisa data dilakukan dengan menggunakan metode analisa kuantitatif yaitu dengan mengumpulkan, mengolah, dan menginterpretasikan data yang diperoleh sehingga memberi keterangan yang benar dan lengkap untuk pemecahan masalah yang dihadapi. Metode analisis data yang digunakan dalam penelitian ini adalah model regresi sederhana dengan menggunakan bantuan software SPSS for window 12.5. Jenis pengujian yang dapat dipakai dalam penelitian ini, yaitu uji asumsi klasik dan pengujian hipotesis.

Regresi linear merupakan suatu metode analisis statistik yang mempelajari pola hubungan antara dua atau lebih variabel. Pada kenyataan sehari-hari sering dijumpai sebuah kejadian dipengaruhi oleh lebih dari satu variabel. Analisis regresi linier berganda memberikan kemudahan bagi pengguna untuk memasukkan lebih dari satu variabel prediktor hingga $\mathrm{p}$-variabel prediktor dimana banyaknya $\mathrm{p}$ kurang dari jumlah observasi (n). Regresi linier berganda, digunakan untuk mengetahui independen variabel mana saja (ketergantungan terhadap smartphone dan sikap), yang merupakan prediktor variabel dependen (Perilaku pembelian online)

$$
Y=\alpha+\beta_{1} X_{1}+\beta_{2} X_{2}+\varepsilon
$$

\section{Keterangan:}

Y: Perilaku Pembelian Online

$\alpha$ : Konstanta

$\beta_{1}$ : Koefisien regresi

$\mathrm{X}_{1}$ : ketergantungan terhadap smartphone

$\mathrm{X}_{2}$ : Sikap 


\section{HASIL PENELITIAN DAN PEMBAHASAN}

Dalam penelitian ini, kuesioner diberikan kepada 60 responden dan kuesioner yang diterima kembali sejumlah 58 kuesioner. Setelah melalui analisis data, ditemukan bahwa data yang memenuhi untuk dianalisis lebih lanjut adalah sebanyak 56 responden. Dari 56 data, responden pria berjumlah 13 orang $(23,2 \%)$ dan responden wanita berjumlah 43 orang $(76,8 \%)$. Sementara, berdasarkan usia, dari 56 data terkumpul sebanyak 9 responden yang berusia 15-18 tahun (16,1\%), usia 19-22 tahun sebanyak 45 responden $(80,4 \%)$ usia 23-35 tahun sebanyak 2 responden (3,6\%). Karakteristik responden berdasarkan asal perguruan tinggi dari data yang terkumpul, sebanyak 15 responden berasal dari IAIN Surakarta (26,8\%), 22 responden berasal dari Universitas Muhammadiyah Surakarta $(39,3 \%)$ dan sisanya 19 orang $(33,9 \%)$ berasal dari STIE AMA Salatiga. Asal uang yang digunakan responden yang masih mahasiswa ini untuk berbelanja yang paling banyak berasal dari uang saku sebanyak 43 responden $(76,8 \%)$, bekerja sebanyak 3 respoden $(5,4 \%)$ dan lainnya sebanyak 10 responden $(17,9 \%) . b T e r a k h i r$ adalah jumlah uang saku responden selama satu bulan, dari 56 data yang terkumpul sebanyak 3 responden memiliki uang saku di bawah Rp. $250.000(5,4 \%)$, 25 responden sebanyak Rp. 250.001 - Rp.500.000 (44,6\%), 16 responden sebanyak Rp. 500.001 - Rp. 1.000 .000 (28,6 \%), dan di atas Rp 1.000.000 (21,4\%) sebanyak 12 responden.

\section{Hasil Uji Validitas dan Reliabilitas}

Pengujian validitas dilakukan dengan Confirmatory Factor Analysis (CFA). CFA ini perlu dilakukan karena dapat menguji apakah suatu konstruk mempunyai unindimensionalitas atau apakah indikator-indikator yang digunakan dapat mengkonfirmasi sebuah konstruk atau variabel. Indikator-indikator masing-masing konstruk yang memiliki loading factor yang signifikan menunjukkan bahwa indicator tersebut merupakan suatu kesatuan alat ukur yang mengukur konstruk yang sama dan dapat memprediksi dengan baik konstruk yang seharusnya diprediksi (Hair et al., 1998). 
Uji validitas dilakukan dengan menggunakan confirmatory factor analysis dengan software SPSS.

Tabel 6

KMO and Bartlett's Test

\begin{tabular}{|ll|r|}
\hline Kaiser-Meyer-Olkin Measure of Sampling Adequacy. & .533 \\
Bartlett's Test of Sphericity & Approx. Chi-Square & 188.947 \\
& Df & 78 \\
Sig. & .000 \\
\hline
\end{tabular}

Sumber: lampiran data diolah

Tabel 7

Rotated Component Matrix

\begin{tabular}{|l|r|r|r|}
\hline & \multicolumn{3}{|c|}{ Component } \\
\cline { 2 - 4 } & 1 & \multicolumn{1}{|c|}{2} & \multicolumn{1}{c|}{3} \\
\hline PPO1 & 0.402 & 0.499 & 0.106 \\
PPO2 & 0.104 & 0.455 & 0.138 \\
PPO3 & 0.348 & 0.73 & -0.072 \\
PPO4 & -0.126 & 0.76 & 0.361 \\
KPO5 & 0.187 & 0.227 & 0.77 \\
KTS1 & 0.053 & 0.732 & 0.048 \\
KTS2 & 0.045 & -0.041 & 0.803 \\
KTS3 & 0.425 & 0.083 & 0.127 \\
KTS4 & 0.064 & -0.011 & 0.07 \\
SKP1 & 0.019 & 0.592 & -0.448 \\
SKP2 & 0.863 & 0.067 & 0.203 \\
SKP3 & 0.755 & 0.173 & 0.187 \\
SKP4 & 0.745 & -0.169 & -0.064 \\
\hline
\end{tabular}

Dengan melihat uji KMO dan Barlett test nilainya adalah $>0,50$, berarti dapat dilakukan analisis faktor. Seperti terlihat dari analisis faktor pada tabel semua item menunjukkan vaditas diatas 0,40. Selanjutnya, pengujian reliabilitas setiap konstruk dilakukan dengan menggunakan koefisien Cronbach's perilaku pembelian online dan ketergantungan terhadap smartphone lebih besar dari 0,60, sedangkan Cronbach's Alpha 
pada perilaku sikap kurang dari 0,60. Hal ini mengindikasikan bahwa pada variabel sikap, ada beberapa responden yang menjawab tidak konsiten.

Tabel 8 Uji Reliabilitas

\begin{tabular}{|c|l|c|c|c|}
\hline \multirow{2}{*}{ No } & \multicolumn{1}{|c|}{ Variabel } & $\begin{array}{c}\text { Corrected item- } \\
\text { Total } \\
\text { Correlation }\end{array}$ & $\begin{array}{c}\text { Cronbach's } \\
\text { Alpha }\end{array}$ & Keterangan \\
\hline 1 & Perilaku Pembelian Online & 0.639 & 0.703 & Reliabel \\
& PPO1 & 0.353 & & \\
& PPO2 & 0.415 & & \\
& PPO3 & 0.464 & & \\
& PPO4 & 0.486 & & \\
& PPO5 & & & \\
& Ketergantungan Terhadap & 0.633 & \\
& Smartphone & 0.309 & & Tidak \\
& KTS1 & 0.487 & & \\
& KTS2 & 0.446 & & \\
& KTS3 & & & \\
& KTS4 & & & \\
\hline \multirow{2}{*}{3} & Sikap & 0.353 & & \\
& SKP1 & 0.418 & & \\
& SKP2 & 0.353 & & \\
& SKP3 & 0.287 & & \\
& SKP4 & & & \\
\hline
\end{tabular}

\section{Pengujian Hipotesis Penelitian}

Pada bagian ini model regresi berganda diterapkan untuk menguji variabel independen yaitu Ketergantungan Terhadap Smartphone, dan Sikap pada variabel dependen yaitu perilaku pembelian online. Pada model regresi berganda ini digunakan SPSS 11.5 for Windows dan pada regresi menggunakan metode enter. Metode enter adalah metode yang memasukkan semua variabel independen kedalam persamaan regresi. Maka dapat ditulis model regresi sebagai berikut

$$
\mathbf{Y}=\alpha+\beta_{1} \mathbf{X}_{1}+\boldsymbol{\beta}_{2} \mathbf{X}_{2}+\mathbf{e}
$$




$$
\begin{aligned}
& \text { Keterangan: } \\
& \text { Y: Perilaku pembelian online } \\
& \alpha: \text { Konstanta } \\
& \beta_{1} \text { : Koefisien regresi variabel } \\
& \mathrm{X}_{1} \text { : Ketergantungan Terhadap Smartphone } \\
& \mathrm{X}_{2} \text { : Sikap }
\end{aligned}
$$

Tabel 9

\section{Persamaan Regresi Berganda}

\begin{tabular}{cccc}
\hline Variabel & $\beta$ & thitung Sig & \\
Konstan & 8.813 & & \\
$\mathrm{X} 1$ & 0,317 & 2,947 & 0,005 \\
$\mathrm{X} 2$ & $-0,019$ & $-0,199$ & 0,843 \\
$\mathrm{R}^{2}$ & $=$ & & \\
\hline \hline
\end{tabular}

Sumber: Olah data

Perilaku Pembelian Online $=8.813+$ 0,317 Ketergantungan Terhadap Smartphone 0,019 Sikap $+\varepsilon$

Karena hasil pada tabel 9 menunjukkan nilai signifikansi sebesar 0.005 (lebih kecil dari $\alpha=5 \%$ ), maka Ho ditolak. Hal ini menunjukkan bahwa Ketergantungan terhadap smartphone (X1) berpengaruh secara signifikan terhadap Perilaku Pembelian Online. Hasil pada tabel 9 juga menunjukkan nilai signifikansi sebesar 0.843 (lebih besar dari $\alpha=5 \%$ ), maka Ho diterima. Hal ini menunjukkan bahwa Sikap (X2) tidak berpengaruh secara signifikan terhadap Perilaku Pembelian Online. 


\section{Koefisien Determinasi}

Untuk menentukan besarnya kontribusi suatu variabel independen (X) terhadap variabel dependen $(\mathrm{Y})$ dapat digunakan koefisien determinasi. Koefisien determinasi secara simultan dapat dilihat dalam tabel model summary sebagai berikut.

Tabel 10

\section{Koefisien Determinasi}

Model Summary

\begin{tabular}{|l|r|r|r|r|}
\hline Model & $\mathrm{R}$ & $\mathrm{R}$ Square & $\begin{array}{c}\text { Adjusted R } \\
\text { Square }\end{array}$ & $\begin{array}{c}\text { Std. Error of the } \\
\text { Estimate }\end{array}$ \\
\hline 1 & $.375^{\mathrm{a}}$ & .141 & .108 & 1.410 \\
\hline
\end{tabular}

a. Predictors: (Constant), SKP, KTS

Dari tabel 10 diatas dapat disimpulkan bahwa nilai koefisien determinasi $\left(\mathrm{R}^{2}\right)$ secara simultan adalah sebesar 0,141, hal ini berarti 14,10\% variabel Perilaku pembelian online dipengaruhi oleh variasi dari kedua variabel independen yaitu ketergantungan terhadap smartphone dan sikap. Sedangkan sisanya sebesar 85,90\% dipengaruhi oleh variabel lain yang tidak diteliti dalam penelitian ini. Dan dari nilai adjusted $R$ square hasilnya adalah 0,108 ini artinya bahwa hasil regresi variabel ketergantungan terhadap smartphone dan sikap terhadap Perilaku pembelian online sebesar 10,8\%.

\section{Uji Signifikansi Simultan}

Tabel 11

\section{Uji Statistik F}

\begin{tabular}{|ll|r|r|r|r|r|}
\hline Model & & Sum of Squares & Df & Mean Square & F & Sig. \\
\hline 1 & Regression & 17.258 & 2 & 8.629 & 4.343 & $.018^{\mathrm{a}}$ \\
& Residual & 105.295 & 53 & 1.987 & & \\
& Total & 122.554 & 55 & & & \\
\end{tabular}

a. Predictors: (Constant), SKP, KTS

b. Dependent Variable: PPO 
Dari uji ANOVA atau $\mathrm{F}$ test didapat nilai $\mathrm{F}$ Hitung sebesar 4, 343 dengan probabilitas 0,018. Karena probabilitas jauh lebih kecil dari 0,05, maka model regresi dapat digunakan untuk memprediksi Perilaku Pembelian Online atau dapat dikatakan bahwa ketergantungan terhadap smartphone dan sikap secara bersama-sama berpengaruh terhadap Perilaku Online.

\section{PEMBAHASAN}

Dari pengujian hipotesis 1 diperoleh hasil bahwa terdapat pengaruh ketergantungan terhadap smartphone pada perilaku pembelian online. Dari hasil tersebut berarti bahwa mahasiwa sangar tergantung pada smartphone mereka, yang mengakibatkan mereka merasa tidak aman jika tidak membawa smartphone. Pengalaman positif mereka dengan smartphone telah mengalahkan pengalaman negatif yang pernah mereka rasakan sehingga penggunaan smartphone menjadi tinggi. Temuan penelitian ini konsisten dengan temuan studi empiris terdahulu yang telah dilakukan oleh Ting et al. (2010) dan Arif et al. (2016). Mahasiswa yang sudah ketergantungan pada smartphone akan merasa lebih nyaman jika aktivitas sehari-hari mereka dapat dilakukan dengan menggunakan smartphone, salah satunya adalah aktivitas belanja. Mereka tidak perlu datang ke toko dan harus berpindah dari satu tempat ke tempat lain yang bisa menguras energi untuk mendapatkan barang yang mereka kehendaki. Dengan menggunakan smartphone belanja akan lebih mudah, apalagi sekarang toko online sudah berkembang pesat di Indonesia.

Berbeda dengan hipotesis 1, hipotesis 2 pada penelitian ini tidak terdukung. Hasil pengujian hipotesis menunjukkan bahwa sikap tidak berpengaruh pada perilaku pembelian online. Lebih lanjut, peneliti melakukan in-depth interview kepada sepuluh orang informan yang sebelumnya menjadi responden dalam penelitian ini, dimana indepth interview ini bertujuan untuk mengetahui lebih dalam pendapat dan alasan dari informan mengenai tidak terdukungnya hipotesis 2 pada penelitian ini. Responden yang dijadikan sebagai informan merupakan responden yang menurut peneliti dapat memberikan informasi yang jelas dan berkualitas. Alasan yang disampaikan oleh mereka adalah kebanyakan dari mereka merasakan adanya kemudahan dalam berbelanja online akan tetapi masih merasakan adanya risiko yang mungkin muncul sehingga mereka 
belum begitu menjadikan belanja online sebagai pilihan utama. Apalagi jika mereka membutuhkan barang mereka tiba dengan sesegera mungkin, terkadang barang yang mereka terima melebihi batas waktu yang telah ditentukan. Belum lagi risiko barang yang mereka terima tidak sesuai dengan pesanan. Hal ini menjadikan sikap mereka masih cenderung hanya masih berupa niat belum sampai ke perilaku untuk melakukan belanja online. Informasi yang disampaikan oleh para responden yang dilibatkan dalam in-depth interview ini sesuai dengan penelitian terdahulu. Lee and Zhang (2002) meyakini bahwa sikap konsumen akan mempengaruhi niat berbelanja online dan pada akhirnya belum tentu niat itu akan dilanjutkan ke pembelian atau tidak. Teori ini sejalan dengan Theory of Reasoned Action (Fishbein and Ajzen, 1975) yang menyatakan bahwa sikap berpengaruh terhadap niat seseorang bukan langsung berpengaruh terhadap perilaku.

\section{KESIMPULAN}

Adapun temuan dari penelitian ini dapat disimpulkan sebagai berikut:

1. Terdapat pengaruh ketergantungan terhadap smartphone yang signifikan terhadap perilaku pembelian online. Dengan adanya perkembangan jaman dimana dunia digital/online yang memudahkan kegiatan manusia, mengakibatkan beralihnya masyarakat khususnya mahasiswa beralih dari metode belanja tradisional ke metode belanja online. Penggunaan smartphone yang sangat tinggi di kalangan mahasiswa juga mempermudah kegiatan belanja mereka. Dengan hanya menggunakan smartphone mereka tidak akan merasa kesulitan keliling antar toko mencari barang yang mereka inginkan, tinggal mencari barang dengan smartphone yang mereka miliki.

2. Tidak terdapat pengaruh sikap yang signifikan terhadap perilaku pembelian online. Mahasiswa hanya memiliki sebatas niat untuk berbelanja online belum sampai tahap perilaku. Hal ini disebabkan karena uang yang mereka miliki untuk berbelanja masih terbatas karena hanya mengandalkan uang saku dari orang tua. Risiko untuk melakukan pembelian secara online juga mereka rasakan masih terlalu besar sehingga mereka masih nyaman untuk melakukan pembelian di toko tradisional. 


\section{DAFTAR PUSTAKA}

Adnan, Hooria (2014), “ An Analysis of the Factors Affecting Online Purchasing Behavior of Pakistani Consumers", International Journal of Marketing Studies, Vol. 6 ,No. 5.

Ajzen, I., \& Fishbein. M. (1980). Understanding attitudes and predicting social behavior. New Jersey, Englewood Cliffs, Prentice-Hall.

Arif, Imtiaz, W.Aslam, dan M.Ali (2016), “Students'dependence on smartphones and its effect on purchasing behavior", South Asian Journal of Global Business Research, Vol. 5, No 2, pp. 285-302.

Dholakia, R. dan Uusitalo, O. (2002), "Switching to electronic stores: consumer characteristics and the perception of shopping benefits", International Journal of Retail \& Distribution Management, Vol. 30 No. 10, hal 459-69.

Duffett, R.G. (2015), "Effect of instant messaging advertising on the hierarchy-of-effects model amid teenagers in South Africa", The Electronic Journal of Information Systems in Developing Countries, Vol. 72 No. 6, pp. 1-21.

Karahanna, E., Straub, D.W. dan Chervany, N.L. (1999), "Information technology adoption across time: a cross section comparison of pre-adoption beliefs and post adoption beliefs", MIS Quarterly, Vol. 23 No. 2, pp. 183-213.

Keaveney, S.M. dan Parthasarathy, M. (2001), "Customer switching behaviour in online services: an exploratory study of the role of selected attitudinal, behavioural, and demographic factors', Journal of the Academy of Marketing Science, Vol. 29 No. 4, pp. 374-90.

Kim, M.-J. dan Parka, J. (2014), "Mobile phone purchase and usage behaviours of early adopter groups in Korea", Behaviour \& Information Technology, Vol. 33 No. 7, pp. 693-703.

Kim, M.-J. dan Parka, J. (2014), "Mobile phone purchase and usage behaviours of early adopter groups in Korea”, Behaviour \& Information Technology, Vol. 33 No. 7, pp. 693-703.

Kuhlmeier, D. dan Knight, J. (2005), "Antecedents to internet based purchasing: a multinational study", International Marketing Review, Vol. 22 No. 4, pp. 460-73. 
Li, Na and Ping Zhang (2002). "Consumer Online Shopping Attitudes And Behavior: An Assessment Of Research", Eighth Americas Conference on Information Systems.

Mafe, C.R. dan Blas, S.S. (2006), “Explaining Internet dependency”, Internet Research, Vol. 16 No. 4, pp. 380-97.

Mantymaki, M. dan Salo, J. (2011), "Teenagers in social virtual word: Continuos use dan purchasing behavior in Habbo Hotel”, Computer in Human Behavior, Vol. 27 pp 2028-2097.

Martinez-Lopez, F.J., Luna, P., \& Martinez, F.J. (2005), “Online shopping, the standard learnin hierarchy and consumers' internet expertise: An American-Spanish comparison. Internet Research, Vol 15 No.3,pp 312-334.

Mohd Suki, N. (2013), "Students' demand for smartphones: structural relationships of product features, brand name, product price and social influence", CampusWide Information Systems, Vol. 30 No. 4, pp. 236-248.

Nazir, S., Tayyab, A., Sajid, A., \& Javed, I. (2012). "How Online Shopping Is Affecting Consumers Buying Behavior in Pakistan?" International Journal of Computer Science Issues (IJCSI), 9(3), 486-495.

Park, Namkee. , Y.K. Kim , H. Shon ,dan H. Shim (2013), "Factors influencing smartphone use and dependency in South Korea", Computers in Human Behavior, Vol. 29, pp 1763-1770.

Schiffman, Leon G dan Leslie L. Kanuk. 2007. Perilaku Konsumen. Jakarta: Indeks.

Sekaran, Uma dan Roger Bougie. (2010), Research Methods For Bussines: Skill Building Approach, $5^{\text {th }}$ ed, John Willey and Sons Ltd.

Smith, S.D. and Caruso, J.B. (2010), "The ECAR study of undergraduate students and information technology", Educause, CO, p. 118.

Ting, Hooi Ting, S.F. Lim, T.S Patanmacia, C.G. Low dan G.C Ker (2011), "Dependency on smartphone and the impact on purchase behavior", Young Consumers, Vol 12, No. 3, pp 193-203 
Yin-Fah, Benjamin Chan dan Hooi-Choo, Bei. (2010), “ Undergraduates and Online Purchasing Behavior", Asian Social Science, Vol. 6, No 10.

Zanna, M. P., \& Rempel, G. (1988). Attitudes: A new look at an old concept. In D. BarTaland \&W. Kruglanski (Eds.), The social psychology of knowledge (pp. 315-334).New York: Cambridge University Press.

\section{Artikel dari Internet}

Setyowati, (2012), "Prospek Belanja Online" diakses dari http://female.kompas.com/read/2012/ 10/05/02371027/prospek.belanja.quotonlinequotc tanggal 4 Juni 2016 